\title{
A Study on Financing Preference of China Electric Power Industry
}

\author{
Xiaoyan Liu \\ School of Business Administration, North China Electric Power University \\ Beijing 110026, China \\ Tel: 86-10-8079-8426Ｅ-mail: 1liu716@sina.com \\ Tao Li \\ School of Business Administration, North China Electric Power University \\ Beijing 110026, China \\ Tel: 86-10-8079-8537Ｅ-mail: litaol@263.net
}

\begin{abstract}
This paper is an analysis of the financing preference of China electric power industry through an empirical analysis method. Through a detailed study using the data of listed electric power companies from 2004-2006, which belongs to the security markets of Shanghai and Shenzhen, We grasp the fact that debt financing is the main method widely used in listed electric power companies, especially long-term debt financing method. This find is very useful for further research on financing effects of to electric power industry, as well as to investors and creditors of the listed electric power companies.
\end{abstract}

Keywords: Financing preference, Listed electric power company, Debt financing

\section{Background of financing in electric power industry in China}

As a basic component industry, electric power industry is playing a more and more important role in the whole economic in China, with a rapid growth. Due to the unique industry characteristics, the economies of scale in electric power industry work significantly. Especially nowadays, pushing forward of electricity reform provides China electric power industry unprecedented new opportunities of development. To some extent, the larger scale, the bigger profit. In order to increase the scale and company Competitiveness, expanding the scale of plant asset is the most effective way. And to expand the scale of plant assets, gathering funds through financing is necessary. Also, the industry advantages provides electric power industry stable and good profitability, thus good solvency. From the fact that the average return on assets of electric power industry is larger than the whole listed company, we can see good solvency is another factor contributing to financing of electric power industry.

The above two factors make up the background of financing of electric power industry in China. Therefore, it is important to research how to finance funds rationally. Most of the domestic current researches regard all listed companies as an overall sample, study of specific industry listed company's capital structure and financing is lacked. This article generalizes the financing preference of electric power industry, and adopts listed electric power companies as samples and analyzes their financing preference status, especially debt financing structure and types. According to capital structure theory, appropriate financing can effectively enhance the value of company

The sample data and industry classifications that we choose derive from the CCER database. After removing companies not suitable, 51 listed electricity power companies of Shenzhen security market and Shanghai market in 2006, belonging to power plate, are selected as research samples.

\section{Analysis of financing methods}

Financing methods of listed power companies mainly contain endogenous financing and exogenous financing. Endogenous financing refers to the company's own funds and funds that come from accumulation of the production and of operation process. Exogenous financing means the part of external funding sources, it relates two sections, that is, equity financing and debt financing. The equity is equity financing activities, such as IPO, lettings and additional, and the debt is debt financing activities that the funds derive from bank, and non-bank lending. 
Table 1 reflects changes of endogenous financing and exogenous of power listed companies between 2004 and 2006. We find that the average of endogenous of power listed companies, in three years, is $17.71 \%$, in other words, the exogenous reaches to $82.29 \%$. Those enclose that most funds of electricity listed companies come from the external market, and accumulation of its own funds to meet the needs plays light effect.

Compared with the whole listed companies, the power listed companies is nearly the same with others, and is different in some extents; The same point is the dominant source of financing is exogenous - the average proportion of all listed companies exogenous financing reaches to $84 \%$, which is lightly higher than the proportion of power listed companies, $83 \%$. The difference is all listed companies prefer to equity financing, with the average percentage of all listed companies $44.09 \%$, and the debt financing proportion $40.75 \%$, opposite of electricity listed companies. 3. Analysis of debt financing structure

In this part, we statistic and analyze the status quo of power listed companies' debt financing structure in China. In the analysis, source projects of debt funds follow debt categories of Balance Sheet in listed companies' annual report.

\subsection{Analyzing Overall Debt Structure}

Table 2 lists overall debt structures of power listed companies and the whole listed companies. As can be seen from the table, the power listed companies' Debt ratios gradually increase for three consecutive years and borrowing increases as well. At the end of 2006, Debt ratios ratio of electricity reached to $55.09 \%$, which is equal to the average level of all listed companies.

Seeing horizontally, long-term liabilities in total of power listed companies are apparently higher than all the others. The table 2 below clearly reflects the situation, such describes that the power listed companies' debt financing has obviously industry characteristics, that is, prefers to long-term liabilities, which are long term and weak mobility.

\subsection{Analyzing debt maturity structure}

Viewing vertically, although the percentage of current liabilities to total liabilities declined between 2004 and 2006, the average level is still up to $71.35 \%$. Additionally, proportion of current liabilities differs with long-term liabilities largely: the ratio of current is 1.5 more than the ratio of long-term. However, long-term liabilities and current liabilities are almost the same in power listed companies, long-term in total liabilities is $52.52 \%$, higher than short-term, which is $47.48 \%$.

Seeing horizontally, long-term liabilities in total of power listed companies are apparently higher than all the others. The chart below clearly reflects the situation, such describes that the power listed companies' debt financing has obviously industry characteristics, that is, prefers to long-term liabilities, which are long term and weak mobility. 3.3 Analyzing debt-types structure

Usually, stakeholders that have creditor relationships with power listed companies mainly are banks, enterprises with business, workers and shareholders, etc. From the table 3, in short-term debt financing structure, short-term debt accounts for the biggest proportion, the average is $42.05 \%$, adding long-term liabilities that due within one year, the proportion of bank credit is the average of $52.35 \%$, following accounts payable notes payable and advance accounts; Those three indexes reflect occupation relationship among companies, occupying current liabilities at the average of $20.29 \%$. As for debt from company employees and shareholders accounts little proportion of current liabilities, at the average of $0.83 \%$ and $0.84 \%$, wages payable decreasing year by year and dividends payable increasing. This indirectly explains that companies make every effort to retain funds, in order to meet the financial needs of business development. The table 3 lists changes of power listed companies in the structure of long-term debt. In electricity listed companies, long-term borrowings dominate long-term debt, at the average of $90.15 \%$, increasing gradually, followed by bonds payable, which reports listed companies issue bonds to raise long-term funding, at the average of $7.09 \%$, the proportion decreasing when compared with long-term borrowings. As for long-term payables, it mainly mirrors that listed companies adopt compensation trade to introduce foreign equipment, lease charges payable of fixed assets, etc., occupying little, only $1.98 \%$. Nevertheless, even though bank credit is the main source of debt capital of the power listed companies; long-term borrowing of some samples is zero. We also find that the number of companies that do not take advantage of the long-term borrowing is reducing. Under the sample distribution of bonds payable, the number of companies that issue bonds to raise funds is rare, and the number of sample, whose bonds payable is 0 , is above $90 \%$. Reasons are that China is strict to issuing bonds.

\section{Summary}

To sum up, the above statistical analysis of financing preference about China listed electric power companies tells us a financing preference of electric power companies completely different from the whole listed companies. After analyzing the financing methods and details of financing structures, we conclude that:

The preferable financing method of power listed companies is external financing. Furthermore, in external financing, the staple is debt financing, supplemented by equity. Such is the opposite of preference of Chinese listed companies as a 
whole, preferring equity financing. And about details, the major external financing approach of the listed electric power companies is long-term liabilities, supported by current liabilities. Such opposes the situation of Chinese security market, the proportion of current liabilities over high.

\section{References}

Chen, Xiaoyue, \& Li, Chen. (1995). An empirical study on the relationship between income and capital structure in Shanghai stock market. Journal of Beijing University, January, pp. 19-21.

Fisher, I. (1933). The Debt Deflation Theory of Great Depression. Econometrica, 1, pp. 217-223.

$\mathrm{Hu}$, Yuancheng. (2002). An Empirical study on the relationship between business capital structure and effectiveness. Management World, October, pp. 146-152.

Richard Barker. (2004). Reporting Financial Performance. Accounting Horizons, 18 (2).

Ross, Stephen. (1997). The determinants of financial structure: The Incentive Signaling Approach. Bell Journal of Economics, August, pp. 46-62.

Wu, Xiaoqiu. (2003). Chinese Listed Company: Capital Structure and Corporation Government. Beijing: China Renmin University Press, 295-319.

Table 1. Internal and External Financing Structure of Listed Enterprises (\%)

\begin{tabular}{|c|c|c|c|c|c|c|}
\hline \multirow{3}{*}{ Year } & \multicolumn{3}{|c|}{ Electric power Listed companies } & \multicolumn{3}{|c|}{ Whole Listed Companies } \\
\hline & \multirow[b]{2}{*}{$\begin{array}{c}\text { Internal } \\
\text { Financing }\end{array}$} & \multicolumn{2}{|c|}{ External Financing } & \multirow{2}{*}{$\begin{array}{c}\text { Internal } \\
\text { Financi } \\
\text { ng }\end{array}$} & \multicolumn{2}{|c|}{ External Financing } \\
\hline & & Equity Financing & Debt Financing & & $\begin{array}{c}\text { Equity } \\
\text { Financing }\end{array}$ & $\begin{array}{c}\text { Debt } \\
\text { Financing }\end{array}$ \\
\hline 2004 & 18.49 & 36.81 & 44.7 & 13.64 & 45.97 & 40.39 \\
\hline 2005 & 17.17 & 32.75 & 50.08 & 15.4 & 43.36 & 41.24 \\
\hline 2006 & 17.47 & 29.9 & 52.64 & 16.45 & 42.93 & 40.63 \\
\hline Average & 17.71 & 33.15 & 49.14 & 15.16 & 44.09 & 40.75 \\
\hline
\end{tabular}

a. "Internal Financing" refers to retained earnings; "Equity financing" is the total of capital stock and additional paid-in capital; "Debt financing" is calculated as the sum of "long-term liability", "short-term liability", "bonds payable" and "long-term accounts payable".

b. The percentages in the table are calculated from the data provided by the CCER database.

Table 2. Financing Structure of Listed Enterprises (\%)

\begin{tabular}{|c|c|c|c|c|c|c|}
\hline \multirow{2}{*}{ Year } & \multicolumn{3}{|c|}{ Listed Electric Power Companies } & \multicolumn{3}{c|}{ Whole Listed Companies } \\
\cline { 2 - 7 } & Debt Ratio & $\begin{array}{c}\text { Current } \\
\text { Liability/ } \\
\text { Total } \\
\text { Liability }\end{array}$ & $\begin{array}{c}\text { Long-term } \\
\text { Liability/ } \\
\text { Total Liability }\end{array}$ & Debt Ratio & $\begin{array}{c}\text { Current } \\
\text { Liability/ } \\
\text { Total } \\
\text { Liability }\end{array}$ & $\begin{array}{c}\text { Long-term } \\
\text { Liability/ } \\
\text { Total } \\
\text { Liability }\end{array}$ \\
\hline 2004 & 47.33 & 46.08 & 53.92 & 52.32 & 75.23 & 24.77 \\
\hline 2005 & 52.68 & 46.94 & 53.06 & 54.39 & 75.71 & 24.29 \\
\hline 2006 & 55.09 & 49.42 & 50.58 & 58.48 & 63.10 & 36.90 \\
\hline Average & 51.70 & 47.48 & 52.52 & 55.06 & 71.35 & 28.66 \\
\hline
\end{tabular}

a. All amounts in the table are calculated by the data from the CCER database.

b. All ratios in the table are consistent with the items in Balance Sheet in the year end. 
Table 3. short-Term Financing Structure of Electric Power Listed Companies (\%)

\begin{tabular}{|c|c|c|c|c|c|c|c|c|}
\hline Year & $\begin{array}{c}\text { Short-term } \\
\text { loans }\end{array}$ & $\begin{array}{c}\text { Long-term } \\
\text { Liabilities } \\
\text { due in 1 year }\end{array}$ & $\begin{array}{c}\text { Accounts } \\
\text { payable }\end{array}$ & $\begin{array}{c}\text { Notes } \\
\text { payable }\end{array}$ & $\begin{array}{c}\text { Prepaid } \\
\text { accounts }\end{array}$ & $\begin{array}{c}\text { Salaries } \\
\text { payable }\end{array}$ & $\begin{array}{c}\text { Dividends } \\
\text { payable }\end{array}$ & Others \\
\hline 2004 & 44.43 & 7.62 & 16.46 & 1.73 & 2.75 & 0.65 & 1.06 & 25.29 \\
\hline 2005 & 36.11 & 15.01 & 13.00 & 3.50 & 2.73 & 0.87 & 1.04 & 27.73 \\
\hline 2006 & 45.61 & 8.26 & 12.56 & 5.10 & 3.04 & 0.96 & 0.43 & 24.05 \\
\hline Average & 42.05 & 10.30 & 14.01 & 3.44 & 2.84 & 0.83 & 0.84 & 25.69 \\
\hline
\end{tabular}

a. "Others" is the sum of "other short-term debts", "taxes payable", and "other accounts payable".

b. All amounts in the table are calculated by the data from the CCER database.

Table 4. Long-Term Financing Structure of Electric Power Listed Companies (\%)

\begin{tabular}{|c|c|c|c|c|}
\hline Year & $\begin{array}{c}\text { Long-term } \\
\text { Liabilities }\end{array}$ & Bonds Payable & $\begin{array}{c}\text { Long-term } \\
\text { Accounts } \\
\text { Payable }\end{array}$ & Others \\
\hline 2004 & 88.18 & 8.89 & 2.33 & 0.59 \\
\hline 2005 & 90.38 & 6.96 & 1.91 & 0.75 \\
\hline 2006 & 91.89 & 5.41 & 1.70 & 1.00 \\
\hline Average & 90.15 & 7.09 & 1.98 & 0.78 \\
\hline
\end{tabular}

a. "Others" is the sum of "other long-term debts", "special accounts payable" and "house funds".

b. All amounts in the table are calculated by the data from the CCER database 